\title{
Influence of Adhesive Type on the Properties of LVL Made from Paricá (Schizolobium amazonicum Huber ex. Ducke) Plantation Trees
}

\section{Utjecaj tipa ljepila na svojstva LVL ploča izrađenih od plantažnog drva paricá (Schizolobium amazonicum Huber ex. Ducke)}

\author{
Original scientific paper • Izvorni znanstveni rad \\ Received-prispjelo: 18. 11. 2014. \\ Accepted-prihvaćeno: 20. 5. 2015. \\ UDK: $630 * 824.3 ; 630 * 833.0 ; 674.031 .738$ \\ doi:10.5552/drind.2015.1438
}

\begin{abstract}
The work aimed at evaluating the influence of the adhesives on physical and mechanical properties of laminated veneer lumber (LVL) boards made from Schizolobium amazonicum plantation trees. This species is native from Amazonia and it is showing fast growing and low density. LVL was produced in three different treatment groups considering the type of adhesive used (Polyvinyl Acetate Crosslinking - PVAc, phenol-formaldehyde $-P F$ and polyurethane-PU). For each treatment, pieces with dimensions of $25 \mathrm{~cm} \times 2.2 \mathrm{~cm} \times 50 \mathrm{~cm}$ were produced. The following mechanical and physical properties were then evaluated: static bending modulus of elasticity $\left(E_{M}\right)$, modulus of rupture $\left(f_{M}\right)$, compression strength parallel to grain $\left(f_{c, 0}\right)$, shear strength parallel to glue-line $\left(f_{v, 0}\right)$, shear strength perpendicular to glue-line $\left(f_{v, 0}\right)$, water absorption and thickness swelling for 2 and 24 h of water immersion. The adhesives used in this study significantly influenced the performance of LVL. Polyurethane adhesive presented better results with respect to physical properties. Phenol-formaldehyde provided greater resistance among the adhesives tested.
\end{abstract}

Key words: Wood products, Lumber, Adhesive, Polyvinyl Acetate Crosslinking, Polyurethane, Phenol-Formaldehyde.

SAŽETAK • Rad je usmjeren na vrednovanje utjecaja ljepila na fizikalna i mehanička svojstva lameliranih furnirskih ploča (LVL) izrađenih od drva Schizolobium amazonicum iz plantažnog uzgoja. Vrsta potječe iz Amazone $i$ ima svojstva brzog rasta i male gustoće drva. LVL ploče proizvedene su primjenom triju vrsta ljepila (polivinil acetatnoga - PVAc, fenol-formaldehidnoga - PF i poliuretanskog ljepila - PU). Dimenzije proizvedenih ploča bile su $25 \mathrm{~cm} \times 2,2 \mathrm{~cm} \times 50 \mathrm{~cm}$. Određivana su ova mehanička i fizikalna svojstva: statički modul elastičnosti pri savi-

\footnotetext{
Author is professor at Federal University of Mato Grosso, Institute of Agricultural and Environmental Sciences, Sinop, MT, Brazil. ${ }^{2}$ Author is professor at Universisty of Brasília, Faculty of Technology, Brasília, DF, Brazil.

Autor je profesor Saveznog sveučilišta Mato Grosso, Institut poljoprivrednih znanosti i znanosti o okolišu, Sinop, MT, Brazil. ${ }^{2}$ Autor je profesor Sveučilišta Brasília, Tehnološki fakultet, Brasília, DF, Brazil.
} 
janju $\left(E_{M}\right)$, modul loma $\left(f_{M}\right)$, čvrstoća na tlak paralelno s vlakancima $\left(f_{c, 0}\right)$, smična čvrstoća paralelno s linijom lijepljenja $\left(f_{v, 0}\right)$, smična čvrstoća okomito na liniju lijepljenja $\left(f_{v, 00}\right)$, apsorpcija vode i debljinsko bubrenje nakon 2 i 24 sata potapanja uzoraka u vodi. Istraživanje je pokazalo da ljepilo upotrijebljeno za izradu LVL ploče znatno utječe na njezina svojstva. Poliuretansko ljepilo utjecalo je na bolja fizikalna svojstva, a fenol-formaldehidno ljepilo pokazalo se najotpornijim među istraživanim ljepilima.

Ključne riječi: proizvodi od drva, drvo, polivinil acetatno ljepilo, poliuretansko ljepilo, fenol-formaldehidno ljepilo

\section{INTRODUCTION 1. UVOD}

The selection of an ideal adhesive to produce structural wood composites depends on different aspects; highlighted among them are the costs, the use of the product, exposure conditions, production method, technology and devices available, the use of treatments and the dimensions and shape of the product (Kurt, 2010). The characteristics of adhesives used in LVL (laminated veneer lumber) production have an important role in the quality of the final product, which can be established based on physical and mechanical properties of the boards. Therefore, the use of a proper adhesive should allow acceptable properties suitable for future use of the panels (Uysal, 2005).

Traditionally, structural wood adhesives are synthetic resins with conditions to promote high durability, resistance and rigidity to structural components produced. The most used resins in LVL production for external use are phenolics, including phenol-formaldehyde and on a smaller scale, resorcinol-formaldehyde (Kol et al., 2010). These adhesives are highlighted because of properties such as high humidity resistance, durability and resistance to microorganism attack that enable more durable final products.

The use of non-phenolic adhesives for LVL production is fundamental, mainly for components with semi-structural or non-structural application. In this way, the improvement of adhesives is already provided, as well as the development of new adhesives made considering the application to products that will be used in dry or humid environments. This aspect enables, for example, the manufacturing of products specific for interior or external use with a satisfactory quality and lower cost, since the use of a resin with high humidity resistance that generally costs more is unnecessary for these applications (Uysal, 2005). In this class, the most commonly used adhesives for LVL production are urea-formaldehyde, melanin-urea-formaldehyde (Çolak et al., 2004; Kurt, 2010), polyvinyl acetate crosslinking (PVAc) and resins based on polyurethanes (Kilic et al., 2006; Kiliç, 2011).

Another relevant aspect to choosing the type of adhesive is the requirement of high temperature for maturing. Hot gluing, necessary for phenol-formaldehyde and urea-formaldehyde adhesives, involves additional costs for board production but accelerates maturing time. Cold gluing (room temperature) used for resorcinol-formaldehyde, polyurethane and PVAc has been used at the industrial level to produce structural components with satisfactory results (Renzo, 2008). Among the main resins used for structural component production, phenol-formaldehyde, and particularly resorcinol-formaldehyde and urea-formaldehyde, have several restrictions on use because of formaldehyde release, even after the adhesive dried (Çolak et al., 2004).

A range of PVA based glues can be formulated to fit the requirements and specifications of many products. The use of PVAc in LVL had good results in studies of Aydin et al. (2004) and Shukla and Kamdem (2008). According to Kim and Kim (2006), there is an increasing interest in the use of PVAc adhesive because of health risks associated to adhesives that contain formaldehyde. Polyurethane adhesive (PU) is formaldehyde-free. It can be found as a mono- or bi-component adhesive, and can be formulated for achieving satisfactory performance related to maturing speed, type of substrate, moisture resistance and mechanical stress. Studies carried out by Kilic (2006), Kiliç (2011) and Bal and Bektas (2012) highlighted good performances of LVL produced with polyurethane-based resins.

This study evaluated the influence of the type of adhesive on physical and mechanical properties of LVL made from paricá (Schizolobium amazonicum Huber ex. Ducke).

\section{MATERIAL AND METHODS 2. MATERIJAL I METODE}

\subsection{Veneer production}

\subsection{Izrada furnira}

Paricá veneers (Schizolobium amazonicum) of $2.71 \mathrm{~mm} \times 85 \mathrm{~cm} \times 115 \mathrm{~cm}$ in thickness, width and length, obtained from PORTIL® - Portas Itinga Limitada and Rio Concrem Industrial Limitada $\AA$, both from Dom Eliseu city, Pará State, were used in this study. Further information about veneer production and yield can be obtained in Melo et al. (2014). Fifty 5-7-year-old Schizolobium amazonicum Huber ex. Ducke (Leguminosae - Caesalpinioideae) trees were harvested and 170-cm length logs were produced and randomly selected in the yard of a plywood facility located in Northern Brazil. The selected logs were peeled within 72 hours after harvesting, and therefore they were still in wet condition.

The veneers without defects were selected, taken to the laboratory and resized into samples of $2.71 \mathrm{~mm}$ x $25 \mathrm{~cm}$ x $50 \mathrm{~cm}$. The samples were then acclimated, and mass and dimensions were measured for later calculation of apparent specific mass. At this step, wave propagation speed was also obtained using a Stress 
Wave Timer device, which was used in conjunction with specific mass $(\rho)$ results, to determine the dynamic modulus of elasticity $\left(E_{\mathrm{md}}\right)$.

\subsection{Adhesive used}

2.2. Primijenjena ljepila

The specifications and features of each resin used for LVL production are described as follows:

Polyvinyl acetate crosslinking (PVAc), bicomponent of Multibond X-080, with catalyzer TSA from Franklin International ${ }^{\circledR}$. The properties observed for this resin were: solid content of $52 \%, \mathrm{pH} 4.5$ and viscosity of $4500 \mathrm{cP}$, according to the specifications of the producer.

CR-070 Phenol-formaldehyde (PF) was used, formulated in the ratio of 100:5:8:7 of resin, wheat flour, coconut flour and water, according to the specifications of the producer SI Group Crios ${ }^{\circledR}$. The viscosity observed for the mixture was approximately $840 \mathrm{cP}$, measured at room temperature with a digital viscometer (spindle \#27), $\mathrm{pH} 11.4$ obtained using a $\mathrm{pH}$ meter and solid content of $59 \%$.

Polyurethane based resin (PU) used was Cascola PU, monocomponent from Henkel ${ }^{\circledR}$, according to the producer ideal for gluing in external areas, as it is waterproof and resistant to different weather conditions and temperatures. According to the producer, resin viscosity is $6000 \mathrm{cP}, \mathrm{pH} 7.0$ and solid content $100 \%$.

\subsection{Manufacturing of panels and sample preparation \\ 2.3. Proizvodnja ploča i izrada uzoraka}

LVL was produced in three different treatment groups considering the type of adhesive used (polyvinyl acetate crosslinking, phenol-formaldehyde and polyurethane). For each treatment, pieces with dimensions of $25 \mathrm{~cm} \times 2.2 \mathrm{~cm} \times 50 \mathrm{~cm}$ (width $\times$ thickness $\mathrm{x}$ length) were produced into $x$-layers LVL. To reduce the variability of properties, boards were assembled through resistance classes according to their $E_{\mathrm{md}}$, with veneers with higher $E_{\mathrm{md}}$ at the outer layers, their values decreasing towards the center layer (more resistant veneers at the face and less resistant veneers at the core). The veneer selection within each class for panel assembly was random.

All adhesives used in the experiment were manually applied using a spatula with a gramature of $200 \mathrm{~g} /$ $\mathrm{m}^{2}$. For pressing, a pressure of $1.0 \mathrm{~N} / \mathrm{mm}^{2}$ was used. LVL produced with PVAc and PU was pressed with a hydraulic presser at room temperature for 12 hours. In the case of PF a cold pre-pressing was made, aided by concrete blocks for 30 minutes following adhesive application. The LVL were then taken to the hydraulic presser and pressed for 12 hours at $140{ }^{\circ} \mathrm{C}$.

\subsection{Determination of properties}

2.4. Određivanje svojstava ploča

For the evaluation of physical properties (specific mass, moisture content, water absorption, thickness swelling and residual swelling) of LVL made from paricá, the recommendations of the ASTM D 1037 standard procedure (1999) were used. Twenty eight samples of wood were used per treatment, with the dimensions of $2.2 \mathrm{~cm} \times 2.2 \mathrm{~cm} \times 10 \mathrm{~cm}$. The samples were acclimated at temperature of $20{ }^{\circ} \mathrm{C} \pm 2$ and $65 \%$ \pm 5 relative humidity, until constant mass was achieved and dimensions and mass could be measured. Following this, specimens were submerged in water and mass and dimensions were measured after 2, 24 and 96 hours following immersion. At the end of the trial, the samples were again taken to the climate chamber, where dimensions and mass were stabilized and these parameters re-measured.

Mechanical tests were carried out according to recommendations of the ASTM D 5456 standard procedures (2006). Two positions for bending resistance flatwise and edgewise, were evaluated. Twenty one samples were used per treatment and per position in the dimensions of $2.2 \mathrm{~cm} \times 2.2 \mathrm{~cm} \mathrm{x} 40 \mathrm{~cm}$. The load was applied at the speed of approximately $2.5 \mathrm{~mm} / \mathrm{min}$. The spacing between supports was $36 \mathrm{~cm}$ in length.

For compression testing, 21 samples were used per treatment with dimensions of $2.2 \mathrm{~cm} \times 2.2 \mathrm{~cm} \times 10$ $\mathrm{cm}$. The specimen dimensions were determined by the maximum ratio of length/radius gyration (17 times) allowed by the standard procedure. The trial speed was 1 $\mathrm{mm} / \mathrm{min}$. Compression for the samples was determined by the force applied at the area subject to stress. For parallel (tension parallel to grain test) and perpendicular (tension perpendicular to grain test) shear stress in relation to glue line, 21 samples with dimensions of 2.2 $\mathrm{cm} \times 2.2 \mathrm{~cm} \times 3.3 \mathrm{~cm}$ and an area for the application of the shear stress were used.

\subsection{Analysis of results}

2.5. Analiza rezultata

The physical tests of water absorption and thickness swelling, and the mechanical trial of static bending were performed using a complete randomized design with factor arrangement. When a significant difference was detected using an F-test, the factors and their interactions were analyzed by the Scott-Knott test $(p>0.05)$. Other results were evaluated using ANOVA with later comparison by Tukey test $(p>0.05)$, also with a completely randomized design.

\section{RESULTS AND DISCUSSION}

\section{REZULTATI I RASPRAVA}

\subsection{Physical properties}

3.1. Fizikalna svojstva

The use of different adhesives for LVL production did not influence the specific mass of the panels (Figure 1). This can be attributed to a pre-classification of the veneers based on $E_{\mathrm{md}}$ and to the same amount of resin used for all treatments $\left(200 \mathrm{~g} / \mathrm{m}^{2}\right)$. The specific mass presented greater values than Iwakiri et al. (2010) observed for LVL made from paricá produced with different assembly strategies and glued with PF. They ranged between $0.37 \mathrm{~g} / \mathrm{cm}^{3}$ and $0.41 \mathrm{~g} / \mathrm{cm}^{3}$.

Regarding equilibrium moisture content, LVL produced with different resins were observed to be significantly different, as the use of PF promoted higher 

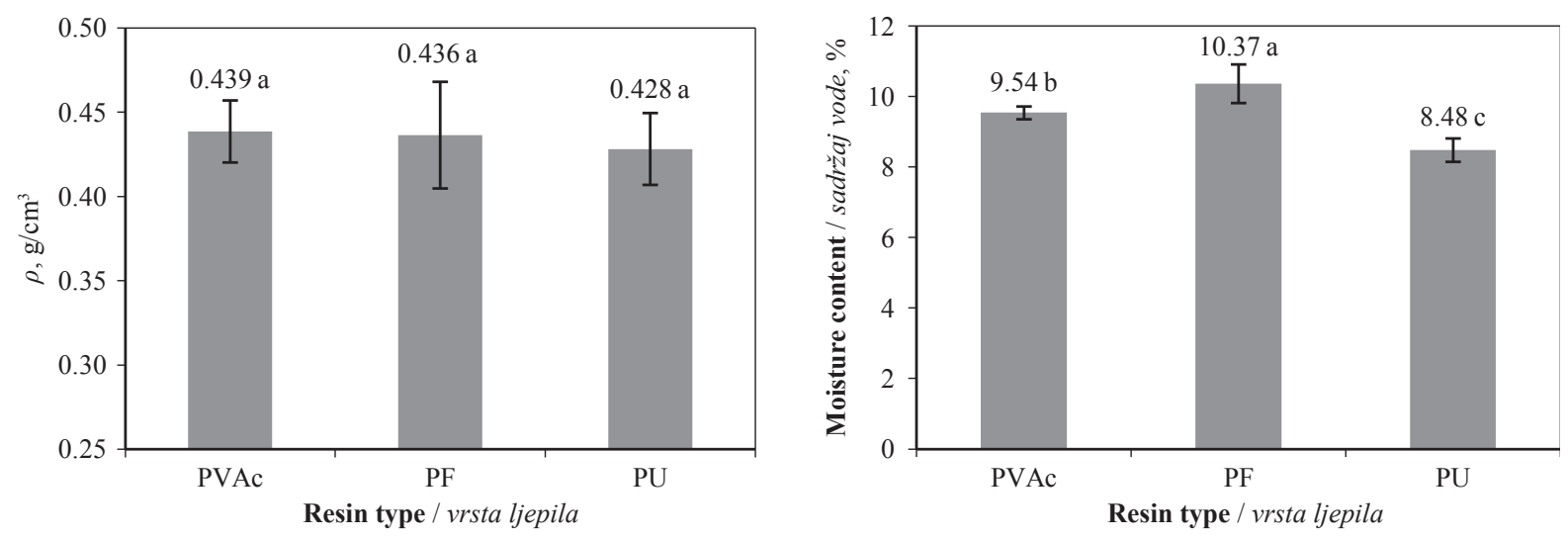

Figure 1 Density $(\rho)$ and equilibrium moisture content observed for LVL panels produced with different adhesives Slika 1. Gustoća $(\rho)$ i ravnotežni sadržaj vode LVL ploča proizvedenih primjenom različitih ljepila

moisture content, followed by PVAc and finally PU. Renzo (2008) studied different adhesive formulations using resorcinol-formaldehyde (RF), tannin and castor bean-based PU and also observed that the type of resin used significantly influenced the equilibrium moisture content in LVL made from Eucalyptus grandis. In addition to the factors that are inherent to the wood itself, aspects related to the manufacturing processes of LVL have an influence on its equilibrium moisture content. Among them, authors mentioned that the type and amount of resin used, and time and temperature of pressing were the factors that differed between the treatments and that could have influenced the results. The same authors also mentioned that equilibrium moisture for reconstituted wood was generally lower in comparison to solid wood for the same temperature and humidity conditions.

Lower moisture content was observed for LVL glued with PU adhesive. This could be explained by the use of water by the adhesive while maturating through the reaction of its isocyanate groups with the water molecules that are present in the wood. This relates to the lower equilibrium moisture content observed in PVAc panels in comparison to PF panels, attributed to a crosslinking process between hydrogen bridges and polyvinyl resin.

For all treatments, the equilibrium moisture content observed was lower than the value from the climate chamber, pre-established at $12 \%$. A similar behavior was observed by Hashim et al. (2011) for LVL made from Hevea brasiliensis. This behavior is explained by different hygroscopicity between products made of wood and solid wood, because of the reduction of the wood into veneers and later the incorporation of resins, paraffin and other substances. Another aspect that contributes to hygroscopicity reduction is the use of high temperatures and pressure on the final consolidation of the LVL panels.

LVL performance in water absorption and thickness swelling tests did not present significant interactions for the evaluated factors (Table 1). This means that the type of adhesive used does not show different behavior for the evaluated times. Consequently, the data were analyzed separately.
Table 1 Summary of results of factorial analysis of water absorption $(W A)$ and thickness swelling $(T S)$

Tablica 1. Sažetak faktorske analize rezultata apsorpcije vode (WA) i debljinskog bubrenja (TS)

\begin{tabular}{|l|c|c|c|}
\hline F.V. & G.L. & $W A$ & $T S$ \\
\hline F1: Adhesive & 2 & $* *$ & $* *$ \\
\hline F2: Time & 2 & $* *$ & $* *$ \\
\hline Interaction F1xF2 & 4 & NS & NS \\
\hline Residue & 180 & & \\
\hline
\end{tabular}

**Significant at the $1 \%$ level $(p<0.01)$ of significance; ${ }^{\text {NS }}$ Not significant $(p>0.05) / * *$ Značajno na razini signifikantnosti $1 \%$ $(p<0,01)$; ${ }^{\text {NS }}$ nije značajno $(p>0,05)$.

Better dimensional stability was observed for LVL produced with $\mathrm{PU}$, followed by the LVL produced with PF (Figure 2). Renzo (2008) proved the efficiency of PU adhesive on dimensional stability for LVL, when it was observed that LVL produced with this resin resulted in a lower percentage of water absorption and thickness swelling when compared with LVL produced using tannin resin, resorcinol resin or a mixture of both. Uysal (2005) compared PU adhesive (D-VTKA) to other kinds of resins (UF, PF and PVAc) and found PF performed better, and PU had similar results to PVAc.

No stabilization of water absorption was observed for the period evaluated. When comparing types of adhesives, LVL produced using PU had lower water absorption, PVAc presented higher water absorption and boards that used PF presented intermediate results (Figure 2). Studies carried out by Uysal (2005) showed different results for LVL made from Pinus sylvestris, where LVL glued with PF absorbed less water compared to LVL that used PU, PVAc and urea-formaldehyde (UF).

For thickness swelling, stabilization was observed 24 hours after immersion, which can be attributed to the fibers achieving saturation point (PSF). Where there was no additional water absorption after this period, interference occurred on the dimensional stability of the component.

The use of different kinds of adhesives promoted a significant difference on residual swelling for LVL made from paricá. This was a repetition of what occurred for thickness swelling, where components that 

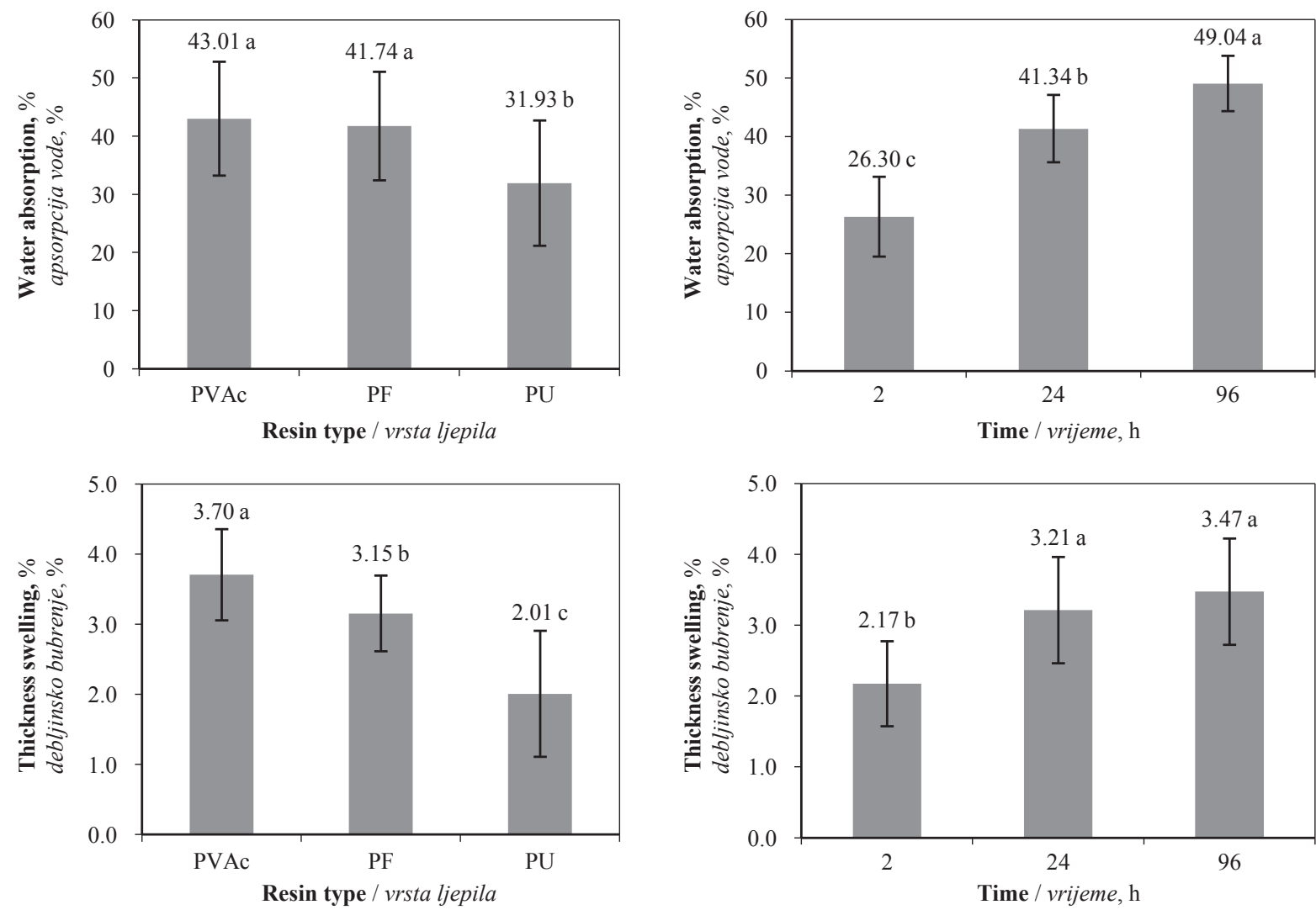

Figure 2 Influence of resin type and immersion time in water absorption and thickness swelling for panels produced with different adhesives

Slika 2. Utjecaj vrste ljepila i vremenskog trajanja potapanja uzoraka u vodi na apsorpciju vode i debljinsko bubrenje LVL ploča proizvedenih primjenom različitih ljepila

used PU presented lower residual swelling. The interrelationships between these parameters were also evidenced by Souza et al. (2011); this evidence confirmed a close relation among parameters of water absorption, thickness swelling and residual swelling for LVL made from different species of Pinus.

Residual swelling is represented by compression stress (springback) to which the samples were exposed during manufacturing (Figure 3). As the pressure used for LVL production was the same for all treatments $\left(1.0 \mathrm{~N} / \mathrm{mm}^{2}\right)$, the results indicate that part of this swelling effect is represented by a loss of adhesion quality that occurred due to long time in which the samples were immersed in water.

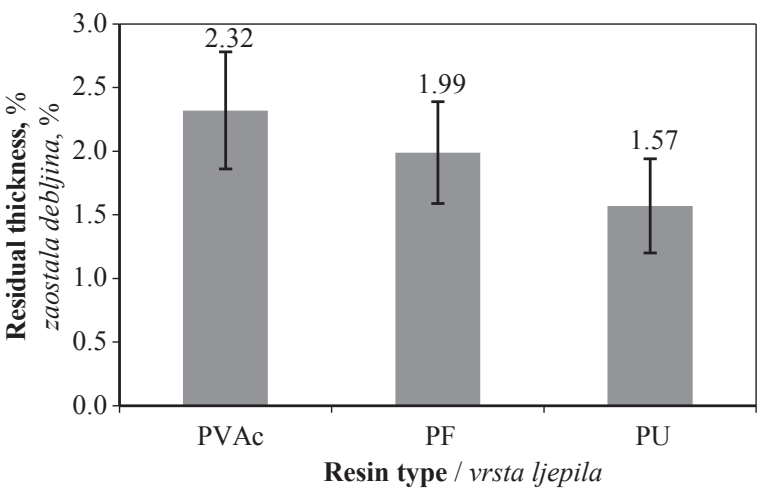

Figure 3 Residual thickness observed for panels produced with different adhesives

Slika 3. Zaostala debljina ploča proizvedenih primjenom različitih ljepila nakon potapanja u vodi

\subsection{Mechanical properties}

\subsection{Mehanička svojstva}

No significant interactions were observed for resistance and rigidity to bending of LVL from paricá between different types of adhesives (PVAc, PF and $\mathrm{PU}$ ) and trials (flatwise and edgewise). These factors however had a significant influence on LVL performance when analyzed individually (Table 2).

Among the types of adhesives used, PF promoted the highest values for $\mathrm{E}_{\mathrm{m}}$, followed by PVAc. For LVL that used PU as an adhesive, it presented greater elasticity (less rigidity) (Figure 4). According to Broughton and Hutchinson (2001), this elasticity is common for products that use PU as an adhesive, because it presents a less rigid bonding line, usually in the form of foam caused by a reaction between the adhesive and wood moisture, producing $\mathrm{CO}_{2}$.

Table 2 Summary of results of factorial analysis for elasticity modulus $\left(E_{m}\right)$ and rupture modulus $\left(f_{m}\right)$

Tablica 2. Sažetak faktorske analize rezultata modula elastičnossti $\left(E_{m}\right)$ i modula loma $\left(f_{m}\right)$

\begin{tabular}{|l|c|c|c|}
\hline F.V. & G.L. & $E_{\mathrm{m}}$ & $f_{\mathrm{m}}$ \\
\hline F1: Adhesive & 1 & $* *$ & $* *$ \\
\hline F2: Type of test & 2 & $* *$ & $* *$ \\
\hline Interaction F1xF2 & 2 & NS & NS \\
\hline Residue & 120 & & \\
\hline
\end{tabular}

**Significant at the $1 \%$ level $(p<0.01)$ of significance; Ns Not significant $(p>0.05) / * *$ Značajno na razini signifikantnosti $1 \%$ $(p<0,01)$; ${ }^{\text {NS }}$ nije značajno $(p>0,05)$. 

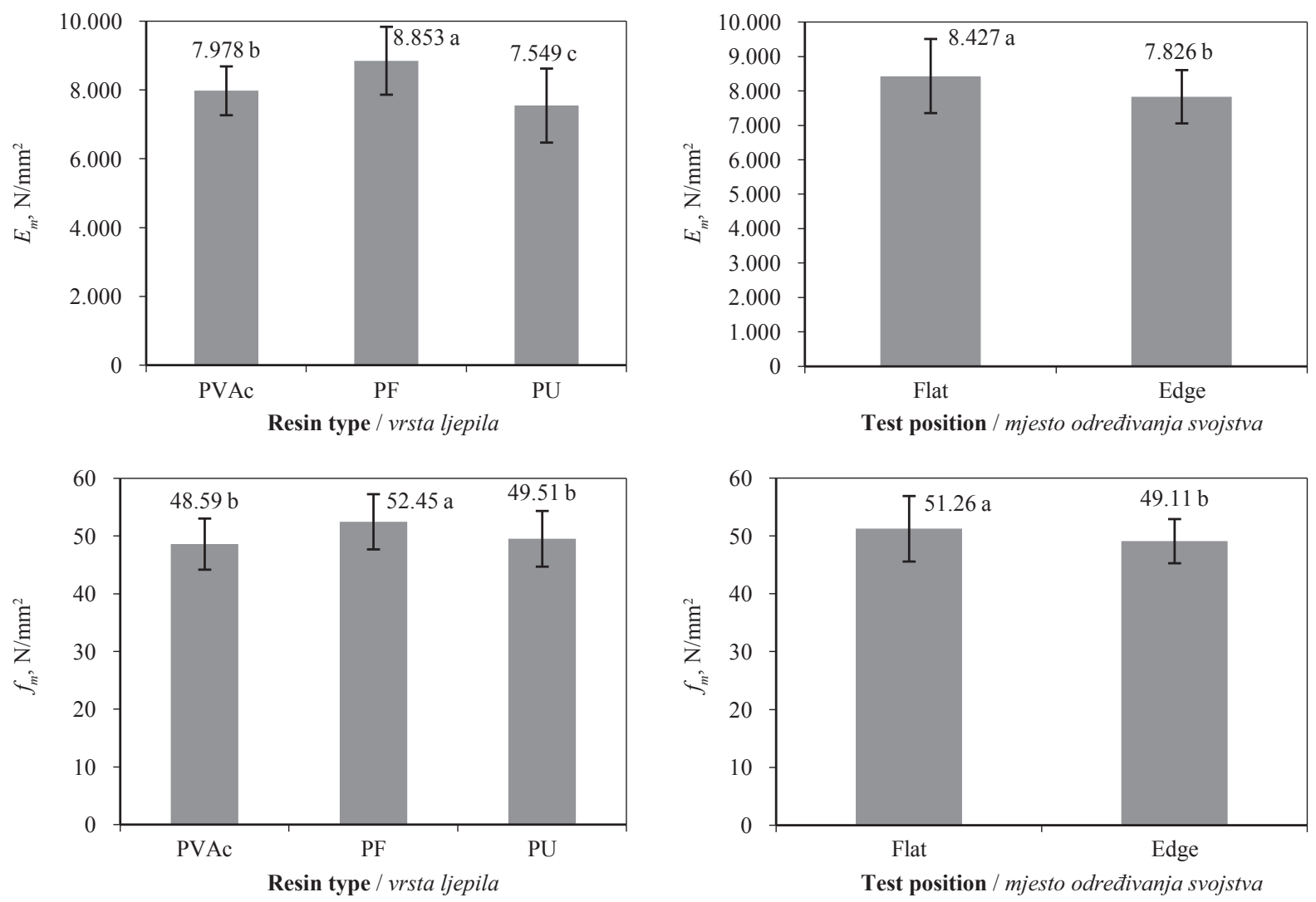

Figure 4 Values of elasticity modulus $\left(E_{\mathrm{m}}\right)$ and rupture modulus $\left(f_{\mathrm{m}}\right)$ of panels according to resin type and test position Slika 4. Vrijednosti modula elastičnosti $\left(E_{\mathrm{m}}\right)$ i modula loma $\left(f_{\mathrm{m}}\right)$ ploča ovisno o vrsti ljepila i poziciji određivanja svojstva

Regarding the $f_{\mathrm{m}}$ parameter, PF was the type of adhesive that was observed to promote a greater bending resistance, while other adhesives presented an equivalent resistance (Figure 4). Kilic et al. (2006) observed for LVL made from Alnus glutinosa that the use of PVA promoted superior mechanical resistance compared to PU adhesive, but for physical water resistance the reverse was observed. However, according to the authors, these results do not regard it impossible to use PVA for structural purposes, since it can be applied to structures in an internal environment. In external areas, the use of PU would be preferred compared to PVA.

Samples in a flatwise trial presented a greater modulus of elasticity $\left(E_{\mathrm{m}}\right)$ and modulus of rupture $\left(f_{\mathrm{m}}\right)$ compared with the edgewise position (Figure 4). This result can be attributed to veneer classification and board assembly that prioritized more resistant veneers for the external layers of LVL. Horizontal laminated systems (flatwise) submitted to bending when more resistant veneers were positioned close to the edges, making it more efficient and resulting in a more resistant laminated component.

Iwakiri et al. (2010) observed that mixed LVL made from paricá (core) and Eucalyptus saligna (covers) had greater bending resistance for both positions of trial (flatwise and edgewise) than LVL produced exclusively from paricá veneers. According to these authors, the arrangements of veneers with a higher specific mass at the face of the LVL, where greater traction stress and compression effort occurred on static bending, were responsible for increased performance. In the same study, it was evidenced that the arrangement of more resistant veneers at the core of the panels did not contribute to increased resistance or rigidity in flatwise position. Müller (2009) observed similar results for mixed LVL made from Pinus taeda and Eucalyptus saligna. This occurred because in static bending trials a multi laminated element is placed on a surface supported by the ends with stress applied in the middle of the interspace, and therefore veneers closer to the surface have to support greater traction stress (inferior face) and compression effort (superior face).

LVL produced with PVAc presented superior parallel compression effort $\left(f_{\mathrm{c}, 0}\right)$ compared to the ones that used PF. LVL that used PU adhesives obtained interme-

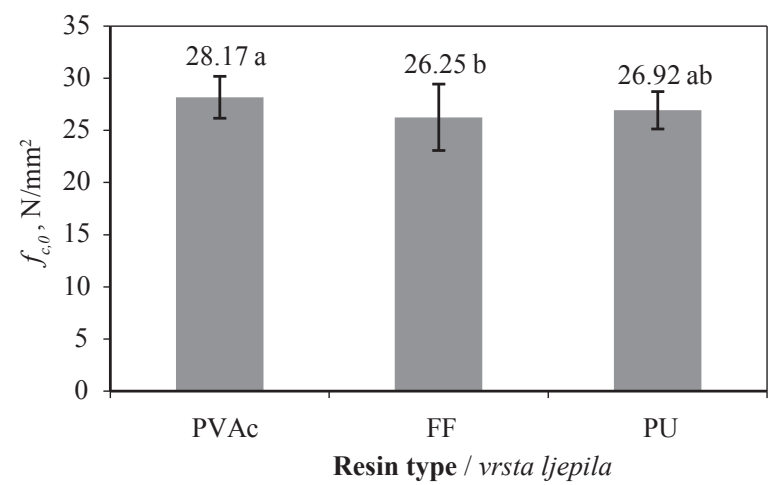

Figure 5 Compression strength $\left(f_{c, 0}\right)$ for panels produced with different adhesives

Slika 5. Čvrstoća na tlak $\left(f_{c, 0}\right)$ ploča proizvednih primjenom različitih ljepila 

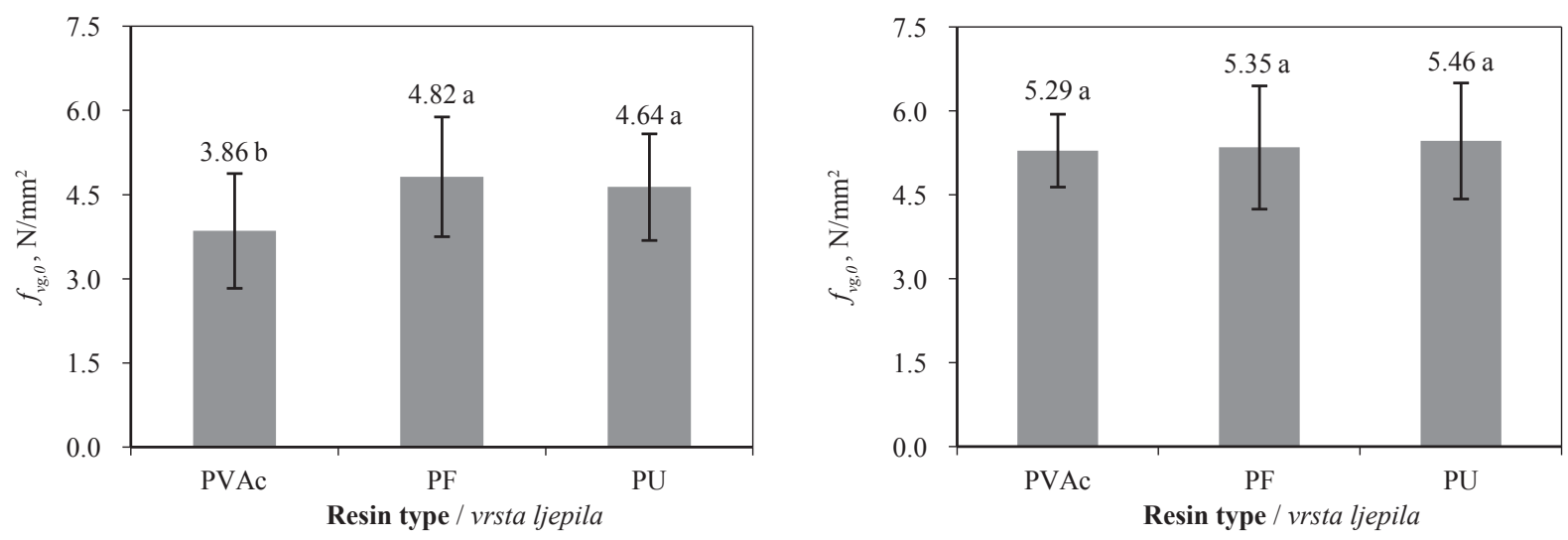

Figure 6 Shear strength parallel $\left(f_{v g, 0}\right)$ and perpendicular $\left(f_{v g, g}\right)$ line of glue to panels produced with different adhesives Slika 6. Smična čvrstoća paralelno $\left(f_{v g, 0}\right)$ i okomito $\left(f_{v g, 90}\right)$ na liniju lijepljenja ploča proizvedenih primjenom različitih ljepila

diate results and at the same time equivalent to the other resins (Figure 5). Similar results were observed by Kilic et al. (2006), who found that among the resins used to produce LVL, PVAc promoted superior results when samples were submitted to effort $f_{c, 0}$. When comparing compression performance of LVL produced with tannin, resorcinol polyurethane or different compositions of these adhesives, Renzo (2008) observed greater compression effort for panels that used PU - $100 \%$.

Analysis of parallel shear resistance $\left(f_{\mathrm{vg}, 0}\right)$ found $\mathrm{PF}$ and $\mathrm{PU}$ as resins that promoted greater resisting connections (Figure 6). These results indicate that the choice of a proper adhesive is essential to obtain a high quality glue line, which can directly affect the LVL performance for parallel shear stress. An example of this was made by Shukla and Kamden (2008), who used PVAc adhesive to produce LVL made from three different species and observed $f_{\mathrm{vg}, 0}$ in the range of 1.8$2.5 \mathrm{~N} / \mathrm{mm}^{2}$. With respect to perpendicular shear stress of the glue line $\left(f_{\mathrm{vg}, 90}\right)$, as shown in Figure 6 the type of adhesive had no significant influence. This result can be attributed to homogenous samples with pre-classification of veneers more than to the type of adhesive used in this trial.

Similar results were obtained by Uysal (2005) when analyzing LVL made from Pinus silvestris and glued with different kinds of adhesive. He observed a greater $f_{\mathrm{vg}, 0}$ for PU adhesives, followed by PF, UF and finally PVAc. Mean values observed by the author were $5.36 \mathrm{~N} / \mathrm{mm}^{2}$ (PU), $4.89 \mathrm{~N} / \mathrm{mm}^{2}$ (PF), $4.77 \mathrm{~N} / \mathrm{mm}^{2}$ (UF) and $4.48 \mathrm{~N} / \mathrm{mm}^{2}$ (PVAc) for a boiling water resistance test. Kilic et al. (2006) compared shear stress parallel to glue line for LVL produced with PVA and PU and concluded that the former adhesive provided greater resistance to the panels.

The values observed for mechanical properties evaluated $\left(\mathrm{E}_{\mathrm{m}}, f_{\mathrm{m}}, f_{\mathrm{c}, 0}, f_{\mathrm{vg}, 0}, f_{\mathrm{vg}, 90}\right)$ for LVL made from paricá can be considered low when compared with results obtained for the same variety of LVL made by different species and glued with many types of resins (Pio, 2002; Uysal, 2005; Souza et al., 2011). It is important to highlight that parallel or perpendicular shear stress does not only depend on adhesive quality but also on the characteristics of the wood used to produce the LVL. Consequently, as observed by Gungor et al.
(2006) and Shukla and Kamden (2008), even when structural adhesives are used, low resistance values can still be obtained.

Since paricá is a wood species with a low specific mass, the young harvested tree samples (4 to 7 years) normally used for commercial veneer production presented low values of shear resistance. To obtain more resistant wood in a population, it is necessary to harvest older trees because they tend to have a higher percentage of adult wood and consequently, a greater specific mass. An example of this is given by Pio (2002), who studied properties of LVL made by veneers of Eucalyptus grandis of different ages (15 to 20 years) and proved that the use of veneers from older trees provided a higher performance on mechanical properties.

\section{CONCLUSIONS}

\section{ZAKLJUČAK}

Different kinds of adhesives used in this study significantly influenced the performance of physicalmechanical properties of LVL made from paricá (Schizolobium amazonicum). In regards to physical properties, polyurethane adhesive presented better results by having lower percentages of water absorption, thickness swelling and residual swelling. For mechanical properties, in a joint analysis of the results, phenolformaldehyde provided greater resistance (except in compression) among the adhesives tested, because it provided better performance when submitted to bending and shear stresses.

\section{REFERENCES}

\section{LITERATURA}

1. ASTM-D-1037, 1999: Standard test methods of evaluating properties of wood-based fiber and particle panel materials. ASTM, USA.

2. ASTM-D-5456, 2006: Standard specification for evaluation of structural composite lumber products. ASTM, USA.

3. Aydin, I.; Colak, S.; Çolakoğlu, G.; Salih, E., 2004: A comparative study on some physical and mechanical properties of laminated veneer lumber (LVL) produced from Beech (Fagus orientalis Lipsky) and Eucalyptus 
camaldulensis Dehn. veneers. Holz Roh-Werkst., 62 (3): 218-220. http://dx.doi.org/10.1007/s00107-004-0464-3

4. Bal, B. C.; Bektaş, I., 2012: The effects wood species, load direction, and adhesives on bending properties of laminated veneer lumber. BioResour., 7 (3): 3104-3112.

5. Broughton, J. G.; Hutchinson, A. R., 2001: Adhesive systems for structural connections in timber. Int. J. Adhes. Adhes., 21 (3): 177-186. http://dx.doi.org/10.1016/s0143-7496(00)00049-x

6. Çolak, S.; Aydin, Ü.; Demürkir, C.; Olakoúlu, G., 2004: Some technological properties of laminated veneer lumber manufactured from pine (Pinus sylvestris L.) veneers with melamine added - UF resins. Turk. J. Agric. For., 28 (2): 109-113.

7. Gungor, N. M.; Ayrilmis, N.; Kantay, R., 2006: Selected physical and mechanical properties of LVL made from Pterocarya fraxinifolia (Clam) Spach. For. Prod. J., 56 (5): 82-85.

8. Iwakiri, S.; Matos, J. L. M.; Pinto, J. A.; Viana, L. C.; Souza, M. M., 2010: Produção de painéis laminados unidirecionais - LVL com lâminas de Schizolobium amazonicum, Eucalyptus saligna e Pinus taeda. Cerne, 16 (4): 557-563. http://dx.doi.org/10.1590/S0104-77602010000400015

9. Kiliç, M., 2011: The effects of the force load direction on bending strength and modulos of elasticity in laminated veneer lumber (LVL). BioResour., 6 (3): 2805-2810.

10. Kilic, Y.; Colak, M.; Baysal, E.; Burdurlu, E., 2006: An investigation of some physical an mechanical properties of laminated veneer lumber manufactured from black alder (Alnus glutinosa) glued with polyvinyl acetate and polyurethane adhesives. For. Prod. J., 56 (9): 56-59.

11. Kim, S.; Kim, H. J., 2006: Study of miscibility of melamine-formaldehyde resin and poly(vinyl acetate) blends for use as adhesives in engi-neered flooring. J. Adhes. Sci. Technol., 20 (2-3): 209-219. http://dx.doi.org/10.1163/156856106775897739

12. Kol, H. S.; Ozbay, G.; Köse, L.; Kurt, S., 2010: Effects of some impregnation chemicals on combustion characteristics of laminated veneer lumber (LVL) produced with oak and poplar veneers. BioResour., 5 (1): 70-80.

13. Kurt, R., 2010: Suitability of three hybrid poplar clones for laminated veneer lumber manufacturing using melamine urea formaldehyde adhesive. BioResour., 5(3): 1868-1878.
14. Melo, R. R.; Del Menezzi, C. H. S.; Pavan, B. E.; Rodolfo Jr., F., 2014: Rotary peeling yield of Schizolobium amazonicum (Leguminosae - Caesalpinioideae). Acta Amaz., 44 (3): 315-320.

http://dx.doi.org/10.1590/1809-4392201302926

15. Müller, M. T., 2009: Influência de diferentes combinações de lâminas de Eucalyptus saligna e Pinus taeda em painéis estruturais LVL. Universidade Federal de Santa Maria, Brazil, 165 p. Master's Thesis.

16. Pio, N. S., 2002: Produção de painéis estruturais de lâminas paralelas (PLP) de Eucalyptus grandis Hill ex-Maiden. Universidade Federal do Paraná, Brazil, PhD Thesis, $168 \mathrm{p}$.

17. Renzo, R., 2008: Painel estrutural de laminas paralelas (PLP) de Eucalyptus grandis utilizando adesivo resorcinólico, taninos e poliuretono derivado de óleo de mamona. Universidade Federal de Lavras, Brazil, Master's Thesis, $115 \mathrm{p}$.

18. Shukla, S.; Kamdem, D., 2008: Properties of laminated veneer lumber (LVL) made with low density hardwood species: effect of the pressure duration. Holz RohWerkst., 66 (2): 119-127. http://dx.doi.org/10.1007/s00107-007-0209-1

19. Souza, F.; Del Menezzi, C. H. S.; Bortolleto Junior, G., 2011: Material properties and nondestructive evaluation of laminated veneer lumber (LVL) made from Pinus oocarpa and P. kesiya. Holz Roh-Werkst., 69 (2): 183192. http://dx.doi.org/10.1007/s00107-010-0415-0

20. Uysal, B., 2005: Bonding strength and dimensional stability of laminated veneer lumbers manufactured by using different adhesives after the steam test. Int. J. Adhes. Adhes., 25 (5) : 395-403.

http://dx.doi.org/10.1016/j.ijadhadh.2004.11.005

\section{Corresponding address:}

Prof. Cláudio Henrique Soares DEL MENEZZI, Ph.D.

Universisty of Brasília

Dept. Forest Engineering, Faculty of Technology

Campus Darcy Ribeiro, PO Box 04357,

70904-970, Brasília, DF, BRAZIL

e-mail: cmenezzi@unb.br 